\title{
Performance Indices and Physiological Changes in Pearl Guinea Fowls (Numida Meleagris) Supplemented with Molasses through Drinking Water
}

\author{
Buhari Habibu*1), Nizam Mustapha Ikira ${ }^{2)}$, Moses Ibrahim $^{2)}$, Hajarah Uwale Buhari ${ }^{2)}$, Abdullahi Abdullahi $^{1)}$, \\ Mohammed Abdul Ibrahim ${ }^{3)}$ and Mohammed Umar Kawu ${ }^{1)}$ \\ ${ }^{1}$ Dept. of Veterinary Physiology, Ahmadu Bello University, Zaria, Nigeria \\ ${ }^{2}$ Samaru College of Agriculture, Division of Agricultural Colleges, Ahmadu Bello University, Zaria, Nigeria \\ 3Poultry Research Programme, National Animal Production Research Institute, Ahmadu Bello University, Zaria, Nigeria \\ *Correspondence author email: buharihabibu@rocketmail.com
}

\begin{abstract}
The study was aimed at evaluating the performance indices and physiological changes in pearl guinea fowls (Numida meleagris) supplemented with molasses through drinking water. A total of thirty-two $(n=32)$ day-old pearl guinea fowls raised to 12-week-old were used for the study. The fowls were randomly allocated to two groups (control and experimental) of 16 fowls each, with each having two replicates. Experimental fowls were given $5 \mathrm{~mL}$ molasses per liter of drinking water for 8 weeks, while control fowls were given only drinking water. Performance indices which include: feed consumption, water intake and percentage weight gain were measured. Rectal temperature was measured and blood samples were collected to evaluate the changes in haematological parameters, serum triiodo thyronine $\left(T_{3}\right)$ and thyroxine $\left(T_{4}\right)$ concentrations. Results revealed that the molasses-treated fowls had significantly $(P<0.05)$ higher percentage weight gain, blood total protein, packed cell volume and mean corpuscular volume compared to control. However, the feed consumption was significantly lower $(P<0.05)$ in the molasses-treated fowls compared to control. In both groups, rectal temperature increased significantly $(P<0.05)$ during the afternoon hours and was lower $(P<0.05)$ in molasses-treated fowls than control during the evening hours. There was no significant difference in other haematological parameters, serum glucose, $\mathrm{T}_{4}$ and $\mathrm{T}_{3}$ betweengroups. In conclusion, molasses supplementation decreased feed consumption, improved body weight gain and enhanced nutritional status and erythropoiesis in guinea fowls.
\end{abstract}

Key words: Weight gain, water intake, rectal temperature, thyroid hormones, haemotological parameters

Abstrak. Penelitian ini bertujuan mengevaluasi indeks performa dan perubahan fisiologis pada ayam mutiara (Numida meleagris) yang disuplementasi dengan molase melalui air minum. Sebanyak 32 ayam mutiara dipelihara hingga usia 12 minggu. Ayam dibagi ke dalam dua kelompok (control dan percobaan) masing-masing 16 ekor dengan dua pengulangan. Ayam percobaan diberikan $5 \mathrm{ml}$ molase per liter air minum selama 8 minggu, sedangkan ayam control hanya diberi air minum. Indeks performa mencakup konsumsi pakan, konsumsi air dan prosentase pertambahan bobot badan. Suhu rectum diukur dan sample darah diambil untuk mengevaluasi perubahan parameter hematologis, konsenstrasi serum triiodo tironin $\left(T_{3}\right)$ dan tiroksin $\left(T_{4}\right)$. Hasil penelitian menunjukkan bahwa ayam yang diberi molase memiliki kenaikan bobot badan, total protein darah packed cell volume dan rataan volume corpuscular yang jauh lebih tinggi $(\mathrm{P}<0.05)$ daripada kelompok kontrol. Namun, konsumsi pakan jauh lebih rendah $(\mathrm{P}<0.05)$ pada ayam yang diberikan molase disbanding kontrol saat siang hari dan lebih rendah $(\mathrm{P}<0.05)$ saat malam hari. Tidak ada perbedaan signifikan di parameter hematologis lain, seru glukosa, , $\mathrm{T}_{4}$ and $\mathrm{T}_{3}$ antar kelompok perlakuan. Disimpulkan bahwa suplementasi molase menurunkan konsumsi pakan, meningkatkan kenaikan bobot badan dan menigkatkan status nutrisi dan erythropoiesis pada ayam mutiara.

Kata kunci: kenaikan bobot badan, konsumsi air, suhu rectum, hormone tiroid, parameter hematologis

\section{Introduction}

Poultry production is the most popular livestock industry in Nigeria, and probably other
West African countries. In recent years, other aspects of poultry production such as quail, turkey and guinea fowl production are increasingly gaining attention in Africa. Thus, it 
is imperative to conduct extensive and intensive study on guinea fowls with the aim of improving the productivity of this species in the nearest future (Onyeanusi, 2007). There are seven species of gallinaceous birds of the family Numididae which bear the common name guinea fowl (Moreki, 2006). In Nigeria, the two main species of guinea fowl that have been described includes: the crested guinea fowl (Gutteraedopuardi) which is found in the rain forest zone and the pearl or helmeted guinea fowl (Numida meleagris) found in the savannah zone, with the latter being the most predominant (Ikani and Dafwang, 2004; Habibu et al., 2016). Guinea fowls attain sexual maturity at about 26-week-old at a body weight of $1.6-1.7 \mathrm{~kg}$ and lay up to 100 eggs in a year (Moreki, 2006). Guinea keets are either fed and managed to become layers or finished to produce table meat. Guinea fowls grown for flesh are exposed to continuous feeding pattern without restriction (Moreki, 2006; Ikani and Dafwang, 2004). This is unlike in the guinea keets managed as a laying stock where feed restriction is practiced at 12 -week-old to when the birds start laying (Moreki, 2006). Their meat is white and delicate, with game-type flavour and high meat to bone ratio, making it a suitable table bird for many African families (Embury, 2001; Ikani and Dafwang, 2004).

Cane molasses is the viscous dark liquid obtained in the industrial preparation of sugar from sugar canes, commonly used as poultry feed ingredient. In addition to the high content of sucrose in molasses, it is also rich in vitamins, particularly the vitamin $B$ complex and minerals, mainly calcium, iron and zinc (Curtin, 1983; Habibu et al., 2014). In chickens, molasses has been used to improve productivity by decreasing feed intake and increasing live weight gain (Rahim et al., 1999; Ndelekwute et al., 2010). Compared with other growth promoters, molasses is affordable even to peasant farmer and also serve as cheap source of vitamins and minerals. Most poultry farms in developing countries are small to medium scale type in which drinking water is given manually using plastic drinkers, thus, making it feasible to administer molasses through drinking water. The use of molasses in drinking water of birds is because it is relatively cheaper and easy to administer using manual plastic drinker (Gultemirian et al., 2014; Habibu et al., 2014).

Previous research has shown that erythrocyte and leucocyte parameters are good tools for evaluating the health and nutritional statuses of guinea fowls and molasses supplementation has been shown to influence the values of these parameters in chickens (Nalubambaet al., 2014; Habibu et al., 2014). Similarly, high blood total protein, serum glucose and thyroid hormones concentration are associated with improved nutritional status in animals (Todini, 2007; Habibu et al., 2016). In chickens, the influence of thyroid hormones on normal growth rate seems to depend on a physiological "set-point", such that administration of triiodothyronine $\left(T_{3}\right)$ to birds with normal circulating concentrations results in adepression in growth rate (Marsh et al., 1984; Bowen et al., 1987; Scanes, 2011). Thus, indicating the important role thyroid hormone play in the growth of birds.

Generally, most research in poultry is focused on chickens leading to a dearth of information in guinea fowl production. This is despite the fact that guinea fowl has been described as a promising genetic resource for evolving a low input-grain saving poultry alternative for production in the developing world (Moreki, 2006). The aim of this experiment is to evaluate the effect of molasses supplementation on performance indices, haematological change and serum thyroid hormones profile of 12 -week-old pearl guinea fowls fattened for a period of 8 weeks.

\section{Materials and Method}

\section{Study location and chicken management}

The study was conducted at the Livestock Unit of the Samaru College of Agriculture, 
Division of Agricultural Colleges, Ahmadu Bello University, Zaria, Nigeria between the third week of January and the second week of March, 2014. The birds were housed in deep liter pen and fed Hybrid ${ }^{\circ}$ grower feed which have nutritional composition similar to that recommended for guinea fowls growers (Table 1; Moreki, 2006; Ikani and Dafwang, 2004). Proximate analysis of the grower feed used in the study is presented in Table 2. Water was provided ad libitum using a round manual poultry drinker and the drinker was washed daily using sponge and water. The round manual drinker was covered with a locally made round-wire mesh to prevent water wastage. The round wire mesh was constructed in such a way that the bird can freely have access to the water. The fenced house was demarcated into four compartments with the pen of different replicate groups being arranged in an opposite and adjacent direction to each other. The house had one main outer door and four inner doors, one for each compartment. The poultry house was made of cement blocks, plastered floor and roofed with a galvanized metal sheets. The fowls of each replicate were kept in a separate pen measuring $4 \mathrm{~m}$ long and $3 \mathrm{~m}$ wide. The house measured $2.5 \mathrm{~m}$ high, with wire mesh on top of the cement blocks and at $1.5 \mathrm{~m}$ to the roof to allow for adequate ventilation.

\section{Experimental design.}

Thirty two ( $n=32$ ) day-old pearl guinea fowls raised to 12-weeksold were used for the study. The fowls were wing-banded, weighed individually and randomly allocated to two groups (Control and Experimental) of 16 fowls each, with each group having two replicates. During the experiment that lasted for 8 weeks, the control fowls were given clean drinking water and were not supplemented with molasses. The experimental fowls were given 5 $\mathrm{mL}$ molasses per liter of drinking water for 8 weeks (Fayomi et al., 2007). Molasses used in the experiment (Table 3) was obtained from Dangote Sugar Refinery, Nigeria.

\section{Measurement of performance indices}

Performance indices which include daily feed consumption, daily water intake and weekly percentage weight gain were measured. The daily feed given to each group of birds was weighed and the amount left in the feeders was also weighed the following day to determine the daily feed intake. Similarly, the amount of water given to each group was measured daily, using a measuring cylinder and the amount left in the drinker was also measured the following day to determine the daily water intake. Weight of the chickens was taken individually at 12and 20-week-old to obtain the initial and final live weights, respectively using Metlar MT5000D Electronic Balance. Percentage weight gain was then calculated from the initial and final live weights.

Table 1. Nutrient composition of the grower diet fed to guinea fowls

\begin{tabular}{lcc}
\hline Nutrients & \multicolumn{2}{c}{ Composition } \\
\cline { 2 - 3 } & Used & Recommended \\
\hline Crud protein (\%) & 15.00 & 15.00 \\
Fat (\%) & 3.6 .00 & - \\
Crude Fibre (\%) & 8.60 & - \\
Calcium (\%) & 1.10 & 1.00 \\
Available Phosphorus (\%) & 0.40 & 0.40 \\
Methionine (\%) & 0.37 & 0.34 \\
Lysine (\%) & 0.70 & 0.82 \\
Metabolizable Energy (Kcal/Kg) & 2500.00 & 1130.00 \\
\hline
\end{tabular}

Sources: Composition of feed Used in the current study (Hybrid Feed ${ }^{\oplus}$, Kaduna, Nigeria) and feed Recommended for guinea fowls (Moreki, 2006) 
Table 2. Proximate analysis of the grower feed used for the study

\begin{tabular}{lc}
\hline Ingredients & Amount \\
\hline Dry matter (\%) & 94.78 \\
Crude protein (\%) & 15.72 \\
Crude fibre (\%) & 5.91 \\
Nitrogen Free Extract (\%) & 66.44 \\
Fat (\%) & 4.82 \\
Ash (\%) & 7.11 \\
\hline
\end{tabular}

Table 3. Nutrient Composition of Molasses

\begin{tabular}{lc}
\hline Ingredients & Amount \\
\hline Moisture (\%) & 19.21 \\
Crude protein (\%) & 5.18 \\
Crude fibre (\%) & 0.00 \\
Nitrogen Free Extract (\%) & 67.86 \\
Fat $(\%)$ & 3.91 \\
Ash $(\%)$ & 3.84 \\
Calcium $(\mathrm{mg} / \mathrm{kg})$ & 7962.00 \\
Iron $(\mathrm{mg} / \mathrm{kg})$ & 1718.35 \\
Zinc $(\mathrm{mg} / \mathrm{kg})$ & 14.93 \\
Copper $(\mathrm{mg} / \mathrm{kg})$ & 6.60 \\
Manganese $(\mathrm{mg} / \mathrm{kg})$ & 7.70 \\
\hline
\end{tabular}

Source: Habibu et al., 2014. Effect of molasses supplementation on live weight gain, haematologic parameters and erythrocyte osmotic fragility of broiler chickens in the hot-dry season.

\section{Determination of rectal temperature}

The body temperature of the molassestreated and control fowls was determined by measuring the rectal temperature for 2 days, 1 week apart in the last week of the experiment (week 8) at 09:00 h, 13:00 h, and 17:00 h using a digital clinical thermometer (Tro-Digitatherm, Hamburg-Germany). The thermometer was inserted approximately $2 \mathrm{~cm}$ into the cloaca and indirect contact with the mucosal wall. The value was recorded after the thermometer made an alarm sound, indicating that the reading had stabilized (Sinkalu et al., 2014).

\section{Determination of haematological parameters and serum thyroid hormones assays}

Blood samples were collected at 20-weekold through the wing vein into vacutainer tubes containing ethylenedeiamine-tetraacetic acid (K3EDTA) for complete blood count and determination of blood total protein and glucose concentration. Serum was collected by allowing the blood without anticoagulant to clot, followed by centrifugation at 2,000 $\mathrm{g}$ for 15 minutes. Packed cell volume (PCV), red blood cell (RBC) count and leucocyte parameters [total leucocyte count (TLC) and differential leucocyte counts] were determined manually, using microhaematocritmethod, hemocytometer and stained slide, respectively as described by Dacie and Lewis (1991). Haemoglobin concentration $(\mathrm{Hb})$ was determined using a haemoglobin meter (XF-1C Hemoglobin meter, China). Erythrocytic indices were calculated from values of PCV, RBC and Hbcount as described by Schalm et al,. (1975).The heterophil-lymphocyte ratio (H:L) was then calculated. The blood total protein was determined using a hand-held clinical refractometer (Atago ${ }^{\circ}$, Master Refractometer, Japan). Postprandial glucose concentration was measured about an hour after the blood was collected usinga glucometer (Accu-chek ${ }^{\circ}$, Roche Diagnostics $\mathrm{GmbH}$, Germany).

Serum thyroid hormone concentrations (total $T_{4}$ and $T_{3}$ ) were measured using a commercial enzyme-linked immunoassay kit (AccuBind ELISA Microwells; Monobind $\mathrm{Inc}^{\circ}$ USA). Assay sensitivities for total $\mathrm{T}_{4}$ and $\mathrm{T}_{3}$ were $3.2 \mathrm{ng} /$ well and $0.04 \mathrm{ng} /$ well, respectively. The intra- and inter-assay coefficients of variation of both $T_{4}$ and $T_{3}$ were less than $10 \%$. All assays were performed in accordance with the manufacturer's instructions.

\section{Meteorological parameter}

The dry-bulb temperature (DBT) and wetbulb temperature (WBT) at the experimental site were measured, using dry- and wet-bulb thermometers (Brannan, England), at 09:00 h, 13:00 $\mathrm{h}$ and 17:00 $\mathrm{h}$ on the days the cloacal temperature was recorded. From the data, relative humidity of each hour was calculated using conversion tables condensed from the Bulletin of the U.S. Weather Bureau No. 1071.

\section{Data analysis}

The values obtained were expressed as mean ( \pm SEM) and subjected to student $t$-test 
for comparison between groups and one-way analysis of variance (ANOVA), followed by Tukey's post-hoc test to compare values of cloacal temperature between hours of the day. The statistical package used was GraphPad Prism version 5.0 for windows (2007) from GraphPad software, San Diego California, USA (www.graphpad.com). Values of $\mathrm{P}<0.05$ were considered significant.

\section{Results and Discussion}

Meteorological parameters (ambient temperature and relative humidity) of the pens were presented in Table 4. The ambient temperature was higher in the afternoon hours, but lower in evening hours. The relative humidity was highest in the evening.

Effect of molasses supplementation on performance indices of guinea fowls was presented in Table 5 and Figure 1. The fowls supplemented with molasses had significantly lower $(P<0.05)$ feed intake compared to control. There was no significant difference in water intake, initial and final weight between control and experimental guinea fowls. However, percentage weight gain was significantly $(P<0.05)$ higher in experimental than control fowls.
Effect of molasses supplementation on rectal temperature of fowls is presented in Table 6. In the evening hours, rectal temperature was significantly $(P<0.05)$ lower in the experimental compared to control, while there was no significant $(P>0.05)$ difference in rectal temperature between groups in the morning and afternoon hours. In both groups, the rectal temperature was significantly $(P<0.05)$ increased in the afternoon, but the decreased in evening hours was not significant $(P>0.05)$.

Table 7 shows the values of blood cellular components of control and experimental fowls. The molasses-treated fowls had significantly higher values of PCV and MCV compared to control. There was no significant difference $(P>0.05)$ in other haematological parameters between control and experimental guinea fowls.

Table 8 indicates the mean values of blood total protein, serum glucose and thyroid hormone concentrations in control and experimental guinea fowls. The value of serum total protein was significantly $(P<0.05)$ higher in experimental compared with control fowls. There was no significant difference in serum glucose and thyroid hormone concentrations between control and experimental guinea fowls.

Table 4. Values of ambient temperature (AT) and relative humidity $(\mathrm{RH})$ in the pen during the study

\begin{tabular}{lcccc}
\hline Parameters & Morning & Afternoon & Evening & Average \\
\hline Ambient temperature & 34.22 & 37.50 & 34.50 & 34.41 \\
Relative humidity & 30.71 & 26.30 & 67.10 & 41.37 \\
\hline
\end{tabular}

Table 5. Mean values of daily water and feed intake in control and molasses treated (Experimental) guinea fowls.

\begin{tabular}{lccc}
\hline Daily intake & Control & Experimental & Range \\
\hline Water $(\mathrm{L} / \mathrm{bird})$ & $0.21 \pm 0.00$ & $0.19 \pm 0.00$ & $0.04-0.29$ \\
Feed $(\mathrm{kg} / \mathrm{bird})$ & $0.06 \pm 0.00$ & $0.05 \pm 0.00^{*}$ & $0.02-0.09$ \\
\hline
\end{tabular}

Values with asterisk $(*)$ indicate significant difference $(\mathrm{P}<0.05)$ compared with control 


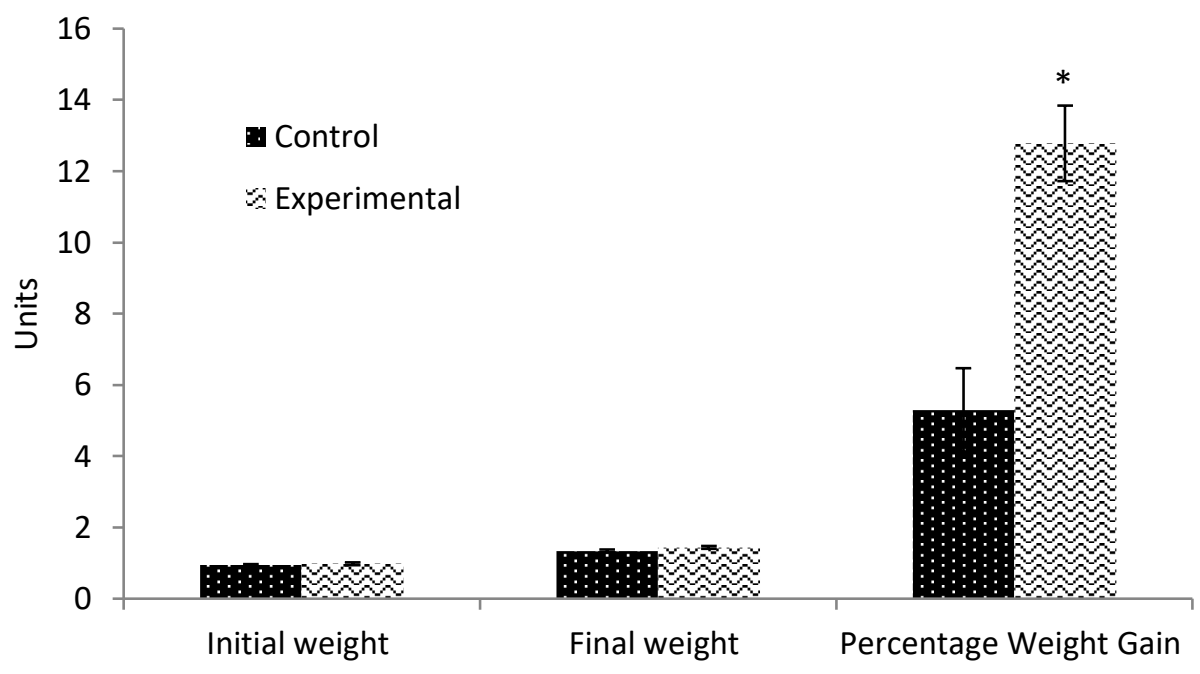

Figure 1. Mean values of initial $(\mathrm{kg})$ and final live weights $(\mathrm{kg})$ and percentage weight gain $(\%)$ in control and molasses treated (Experimental) guinea fowls. Value with asterisk $(*)$ indicates significant difference $(\mathrm{P}<0.05)$ compared with control

Table 6. Mean values of cloacal temperature in the morning, afternoon and evening in control and molasses treated (Experimental) guinea fowls.

\begin{tabular}{llll}
\hline Hour of the day & Control & Experimental & Range \\
\hline Morning $(09: 00 \mathrm{~h})$ & $41.53 \pm 0.22^{\mathrm{a}}$ & $41.81 \pm 0.129^{\mathrm{a}}$ & $40.00-42.80$ \\
Afternoon $(13: 00 \mathrm{~h})$ & $42.54 \pm 0.1^{\mathrm{b}}$ & $42.69 \pm 0.08^{\mathrm{b}}$ & $41.70-43.7$ \\
Evening $(17: 00 \mathrm{~h})$ & $42.75 \pm 0.19^{\mathrm{b}}$ & $42.25 \pm 0.14^{\mathrm{b} *}$ & $41.10-43.80$ \\
\hline
\end{tabular}

Values with superscripts $(a, b)$ within column and asterisk $\left({ }^{*}\right)$ with row, compared with control are significantly difference $(\mathrm{P}<0.05)$

Table 7. Mean ( \pm SEM) values of haematological parameters in control and molasses treated (Experimental) guinea fowls.

\begin{tabular}{lccc}
\hline Parameters & Control & Experimenta & Range \\
\hline $\mathrm{PCV}(\%)$ & $31.18 \pm 0.42$ & $33.81 \pm 0.99^{*}$ & $29.40-39.60$ \\
$\mathrm{RBC}\left(10^{6} / \mu \mathrm{L}\right)$ & $2.31 \pm 0.02$ & $2.41 \pm 0.08$ & $2.14-2.87$ \\
$\mathrm{HB}(\mathrm{g} / \mathrm{dL})$ & $17.33 \pm 0.41$ & $18.32 \pm 0.57$ & $16.10-22.60$ \\
$\mathrm{MCV}(\mathrm{fL})$ & $135.50 \pm 0.81$ & $140.30 \pm 0.62^{*}$ & $132.70-143.40$ \\
$\mathrm{MCH}(\mathrm{pg})$ & $75.15 \pm 1.65$ & $77.06 \pm 0.99$ & $68.20-80.70$ \\
$\mathrm{MCHC}(\mathrm{g} / \mathrm{dL})$ & $55.52 \pm 1.02$ & $54.99 \pm 0.59$ & $51.10-58.80$ \\
$\mathrm{TLC}\left(10^{6} / \mu \mathrm{L}\right)$ & $6.41 \pm 0.46$ & $5.98 \pm 0.57$ & $4.00-9.00$ \\
$\mathrm{LYMPH}(\%)$ & $83.89 \pm 1.26$ & $80.30 \pm 3.87$ & $55.00-92.00$ \\
NEUT $(\%)$ & $15.89 \pm 1.33$ & $14.11 \pm 1.88$ & $8.00-24.00$ \\
$\mathrm{H}: \mathrm{L}$ & $0.18 \pm 0.03$ & $0.17 \pm 0.03$ & $0.02-0.32$ \\
\hline
\end{tabular}

$\mathrm{PCV}=$ packed cell volume, $\mathrm{RBC}=$ red blood count, $\mathrm{Hb}=$ haemoglobin concentration, $\mathrm{MCV}=$ mean corpuscular volume, $\mathrm{MCH}=$ mean corpuscular haemoglobin, $\mathrm{MCHC}=$ mean corpuscular haemoglobin concentration, $\mathrm{TLC}=$ total leucocyte count, LYMPH (\%) = percentage lymphocyte count, NEUT $(\%)=$ percentage neutrophil count, $\mathrm{H}: \mathrm{L}=$ heterophil-lymphocyte ratio. Values with asterisk $\left({ }^{*}\right)$ indicate significant difference $(\mathrm{P}<0.05)$ compared with control 
Table 8. Mean ( \pm SEM) values of blood total protein $(T P)$, serum glucose, triiodothyronine $\left(T_{3}\right)$ and thyroxine $\left(T_{4}\right)$ in control and molasses treated (Experimental) guinea fowls

\begin{tabular}{lccc}
\hline Parameters & Control & Experimental & Range \\
\hline $\mathrm{TP}(\mathrm{g} / \mathrm{L})$ & $5.49 \pm 0.11$ & $5.84 \pm 0.09^{*}$ & $5.00-6.20$ \\
Glucose $(\mathrm{g} / \mathrm{L})$ & $262.40 \pm 11.66$ & $309.60 \pm 18.01$ & $234.00-386.00$ \\
$\mathrm{~T}_{3}(\mathrm{ng} / \mathrm{L})$ & $2.44 \pm 0.27$ & $2.14 \pm 0.24$ & $1.80-2.84$ \\
$\mathrm{~T}_{4}(\mathrm{ng} / \mathrm{L})$ & $12.75 \pm 0.99$ & $10.20 \pm 0.42$ & $7.75-16.00$ \\
\hline
\end{tabular}

Value with asterisk $(*)$ indicates significant difference $(\mathrm{P}<0.05)$ compared with control

Table 9: Percentages of $T_{3}$ in relationship to $T_{4}$ in the current study and other studies

\begin{tabular}{ccccc}
\hline $\begin{array}{c}\text { Current study, } \\
\mathrm{ng} / \mathrm{L}\end{array}$ & $\begin{array}{c}\text { Tanyi et al., (1994; guinea } \\
\text { fowls), } \mathrm{nmol} / \mathrm{L}\end{array}$ & $\begin{array}{c}\text { Raeesi et al., (2012; broiler } \\
\text { chickens) } \mathrm{ng} / \mathrm{L}\end{array}$ & $\begin{array}{c}\text { Todini, (2007; most } \\
\text { mammals), } \mathrm{ng} / \mathrm{L}\end{array}$ \\
\hline $\mathrm{T}_{3}$ & $2.30(16.70 \%)$ & $1.18(33.9 \%)$ & $1.42(4.3 \%)$ & $0.87(2 \%)$ \\
$\mathrm{T}_{4}$ & $11.47(83.30 \%)$ & $2.30(66.1 \%)$ & $31.7(95.5 \%)$ & $71.7(98 \%)$ \\
\hline
\end{tabular}

The mean values of daily water intake in molasses treated guinea fowls was $0.19 \mathrm{~L} / \mathrm{bird}$, thus, the average amount of molasses consumed by the fowls daily was $0.95 \mathrm{~mL} /$ bird. There was no significant difference in initial (Range: 0.72-1.19) and final weight (Range: 1.13-1.77) between control and experimental guinea fowls. However, the fowls supplemented with molasses consumed less feed, but had higher percentage weight gain compared with control. This agrees with the findings of Rahim et al. (1999) and Ndelekwute et al. (2010) in chickens in which molasses supplementation reduced feed intake and increase weight gain. On the contrary, molasses supplementation in chickens has been shown to increase weight gain, with no significant effect on feed intake compared with control (Fayomi et al., 2007; Habibu et al., 2014). The high nutritive values of molasses and the increase in production of short chain fatty acids (SCFA) in the caecum of molasses treated fowls may be responsible for the high weight gain despite the low feed intake (Perez, 1995; Gultemirian et al., 2014; Habibu et al., 2014). Any carbohydrate that reached the cecum serves as potential substrate for fermentation by microbes to produce SCFA (Gultemirian et al., 2014). Like other oligosaccharide containing feed supplements, such as polymonnuronate (Zhu et al., 2015) and lactulose (Calik and Ergun, 2015), molasses which contains 32-42\% sucrose (Perez, 1995) has been reported to also increase the production of SCFA in the caecum of chickens (Gultemirian et al., 2014). Short chain fatty acids prevent the growth of pathogenic microbes such as E. coli, Salmonella spp., Clostridium spp. and Campylobacter spp. (Boguslawska et al., 2015; Meimandipour et al., 2010; Arsi et al., 2015) by lowering the $\mathrm{pH}$ to create an unconducive environment around the pathogens (Savage, 1991).On the other hand,SCFA favour the selective colonization of the gastrointestinal $\operatorname{tract}(\mathrm{GIT})$ by beneficial microbes such as lactobacillus spp., Bifidobacteria ssp. and Bacillus subtilis(Biggs et al.,2007; Janardhana et al., 2009; Kim et al., 2011; Park and Kim, 2014; Zhu et al., 2015). They also serve as major source of energy to enterocytes and colonocytes (Chapman et al., 1995, Ahmad et al., 2000), and have a fundamental role in maintaining the health and integrity of the GIT (Roediger and Nance, 1986; Meimandipour et al., 2010); probably via enhancing differentiation and proliferation of the intestinal mucosa (Rinttila and Apajalaht, 
2013). The improved GIT health and integrity occasioned by the increase in production of SCFA may explain the increased blood total protein in the treated group compared to control. Similarly, high blood total protein has been reported in guinea fowls supplemented with mannan oligosaccharide (Oso et al., 2014) and a combination of probiotics and prebiotic (Habibu et al., 2016). In birds, high serum total protein is associated with high dietary protein utilization and improved nutritional status (Church et al., 1984; Luiet al., 2015).In agreement with the finding of the current study, Elgilani (2000), also reported that supplementation of molasses through feed has no effect on serum glucose concentration in chickens.

Significant diurnal variation was observed in the rectal temperature of guinea fowls between the morning and afternoon hours, irrespective of treatment. In the evening, the rectal temperature was lower in treated compared with control fowls. This is comparable to the finding of Fayomi et al. (2007) who reported a reduction in rectal temperature of chickens supplemented with molasses and molavit. Therefore, this suggests the potential of molasses to combat the hyperthermia associated with heat stress.

The values of blood cellular components recorded in the present study are within the normal range reported by Adedibu et al. (2014). The high PCV in treated fowls compared to control in the present study is likely due to the higher MCV (average size of individual erythrocytes) in the fowls supplemented with molasses. Younger erythrocytes are larger than older ones and thus, will have higher MCV (Nash and Wyard, 1981). Accordingly, the high MCV may suggest a more active or enhanced erythropoiesis in the molasses treated fowls. This confirms previous report, in which MCV was higher in chickens supplemented with molasses (Habibu et al., 2014). The ability of
SCFA to increase iron absorption (Gultemirian et al., 2014) and the improved nutritional status may be responsible for the enhanced erythropoiesis in molasses treated fowls.

Serum thyroid hormone is routinely used as an indicator of the nutritional status of animals (Riis and Madsen, 1985; Todini, 2007).In the current study, molasses supplementation has no effect on serum levels of $T_{3}$ and $T_{4}$ in fowls. Percentage of serum $T_{4}$ relative to $T_{3}$ has been demonstrated in both mammals and birds. For instance, percentage of serum $T_{4}$ relative to $T_{3}$ has been reported to be $98 \%$ to $2 \%$ in mammals (Todini, 2007), and $95.5 \%$ to $4.5 \%$ in broiler chickens (Raeesim et al., 2012). In guinea fowls, however, lower percentage of $\mathrm{T}_{4}(83.30 .77 \%)$ and higher percentage of $\mathrm{T}_{3}(16.70 \%)$ compared with mammals was observed in the current study. This agrees with a previous study that reported lower percentage of $\mathrm{T}_{4}$ (66.1\%) relative to $T_{3}(33.9 \%)$ in guinea fowls compared with mammals (Tanyi et al.,1994). The relatively higher percentage of $\mathrm{T}_{3}$ and low percentage of $\mathrm{T}_{4}$ is likely due to the increase in the conversion of $T_{4}$ to $T_{3}$ by deiodinase enzymes. Triiodothyronine $\left(T_{3}\right)$ is the bioactive form of thyroid hormone which expresses most of its physiological effects by binding to nuclear receptors of target tissue to stimulate an increase utilization of oxygen and the production of heat in all cells of the body (Todini, 2007Lesmanaet al., 2015). Thus, the higher percentage of $T_{3}$ relative to $T_{4}$ in guinea fowls compared with mammals may explain the hyperactivity, high metabolic rate and rectal temperature in this bird.

\section{Conclusions}

Molasses supplementation through drinking water decreased feed consumption, improved body weight gain and enhanced nutritional status and erythropoiesis in guinea fowls. Molasses supplementation at $5 \mathrm{~mL} / \mathrm{L}$ drinking 
water is beneficial to guinea fowls and can be administered to improve productivity.

\section{Acknowledgement}

We acknowledge the Director of Division of Agricultural Colleges (DAC) and management of Samaru College of Agriculture, Ahmadu Bello University, Zaria, Nigeria for providing us with guinea fowls, molasses and relevant facilities and the technical staff of the Department of Veterinary Physiology, Ahmadu Bello University, Zaria for their technical assistance.

\section{References}

Adedibu II, KL Ayorinde and AA Musa. 2014. Identification of hematological markers suitable for improving productivity of helmetedguinea fowl Numidameleagris. Am. J. Exp. Agric. 4:11861196.

Ahmad MS, S Krishnan, BS Ramakrishna, M Mathan, AB Pulimood and SN Murthy.2000.Butyrate and glucose metabolism by colonocytes in experimental colitis in mice. Gut. 46:493-499.

ArsiK,AM Donoghue,A Woo-Ming,PJ Bloreand DJ Donoghue. 2015. The efficacy of selected probiotic and prebiotic combinations in reducing Campylobacter colonization in broiler chickens. J. Appl. Poult. Res.24:327-334.

Biggs P, CM Parsons and GC Fahey.2007.The effects of several oligosaccharides on growth performance, nutrient digestibilities and cecal microbial populations in young chicks. Poult. Sci. 86:2327-2336.

Bogusławska-Tryk M, R Szymeczko, APiotrowska, K Burlikowska and K Śliżewska. 2015. Ileal and cecal microbial population and short-chain fatty acid profile in broiler chickens fed diets supplemented with lignocellulose. Pakistan Vet. J. 35:212-216.

Bowen SJ, LM Huybrechts, JA Marsh and CG Scanes.1987.Influence of triiodothyronine and growth hormone on growth of dwarf and normal chickens: interactions of hormones and genotype. Comp. Bioch.Physiol. A Comp. Physiol. 86:137-142.

Calik A and AErgun. 2015. Effect of lactulose supplementation on growth performance, intestinal histomorphology, cecal microbial population, and short-chain fattyacid composition of broiler chickens. Poult. Sci. 94: 2173-82.
Chapman MA, MF Grahn, M Hutton and NS Williams. 1995. Butyrate metabolism in the terminal ileal mucosa of patients with ulcerative colitis. Br. J. Surg. 82:36-38.

Church JO, JJ Judd, CW Young, JL Kebay and WW Kim. 1984. Relationship constituents and specific serum clinical components of subjects eating self selected diets. Am. J, Clin. Nutr. 40: 1338-1344.

Curtin LV. 1983.Molasses - general considerations. National Feed Ingredients Association, West Des Moines, lowa, USA.

Dacie JV and SM Lewis. Practical hematology, $7^{\text {th }}$ Edn.Churchill Livingstone Edinburg, London, UK. 1995.

Elgilani HM. 2000.The feeding value of sugar cane molasses in broiler diets. MSc. Thesis, University of Khartoum.

Fayemi A, NS Minka, JO Ayo, JA Nwanta, A Mohammed and EJ Alaya. 2007. Effect of molasses or molavit supplementation on rectal temperature, live weight gain and haematology of cockerel during Harmattan season in Northern Nigeria. Nigerian Vet. J. 28:34-40.

Gultemirian ML, HR Corti, AP Chaia and MC Apella. 2014. Fermentation in vitro of a mixture of dietary fibers and cane molasses by the cecal microbiota: Application on mineral absorption through the laying hen's colonic epithelium. Anim. Feed Sci. Technol. 191:79-82.

Habibu B., NM Ikira, M Ibrahim, HUBuhari, MU Kawu, LS Yaquband T Aluwong. 2016. Effect of Dietary Combination of Probiotics and Prebiotic on Performance Indices and Haematological Parameters in Pearl Guinea Fowls (Numidameleagris) J. Anim. Res. 6:7-13.

Habibu B, NM Ikira, HU Buhari, T Aluwong, MU Kawu, LS Yaqub, M Tauheed and HI Isa. 2014. Effect of molasses supplementation on live weight gain, haematologic parameters and erythrocyte osmotic fragility of broiler chickens in the hot-dry season. Int. J.Vet. Sci. 3:181-188.

Ikani El and II Dafwang.2004.The production of guinea fowl in Nigeria. National Agricultural Extension and Research Liaison Services (NAERLS) Extension Bulletin, 207(8): 1-28.

Janardhana V, MM Broadway, MP Bruce, JW Lowenthal, MS Geier, RJ Hughes and AG Bean. 2009. Prebiotics modulate immune responses in the gut-associated lymphoid tissue of chickens. J. Nutri. 139:1404-1409.

Kim GB, Seo YM, Kim CH, and Paik IK. 2011. Effect of dietary prebiotic supplementation on the performance, intestinal microflora, and immune response of broilers. Poult Sci. 90:75-82.

Marsh JA, TJ Lauterio, and CG Scanes. 1984. Effects of triiodothyronine treatments on body and 
organ growth and development of immune function in dwarf chickens. Proc. Soc. Exp.Biol Med.117:82-91.

Meimandipour A, M Shuhaimi, AF Soleimani, K Azhar, M Hair-Bejo, BM Kabeir, AJavanmard, OM Anas and AM Yazid. 2010. Selected microbial groups and short-chain fatty acids profile in a simulatedchicken cecum supplemented with two strains of Lactobacillus.Poult. Sci. 89: 470-476.

Moreki JC. 2006. Guinea fowl production. www.gov.bw/Global/MOA/Guinea\%20Fowl \%20Production.pdf.

Nalubamba KS, NB Mudenda, EC Bwalya, M Masuku, M Munyeme and HM Munangandu. 2014. Seasonal variations in health indices of freeranging asymptomatic guinea fowls (Numidameleagris) in Zambia. Asian Pacific J. Trop. Med. 7: S143-S149.

Nash GB and SJ Wyard.1981.Erythrocyte membrane electricity during in vivo ageing. Biochim. BiophysActa, 642:269-273.

Ndelekwute EK, HO Uzegbu, IR Igwe, RJNosike, VU Odoemelam and UO Inyan. 2010. Effects of administration of molasses through drinking water on growth and conformation parameters of meat-type chicken. Anim. Prod. Res. Adv. 6:30-34

Lesmana R, RA Sinha, BK Singh, J Zhou, K Ohba, Y Wu, WWY Yau, B Bay and PM Yen. 2015. Thyroid hormone stimulation of autophagy is essential for mitochondrial biogenesis and activity inskeletal muscle. Endocrinol. DOI: 10.1210/en.2015-1632.

Liu QW, JH Feng, Z Chao, Y Chen, LM Wei, F Wang, RP Sun and MH Zhang. 2015. The influences of ambient temperature and crude protein levels on performance and serum biochemical parameters in broilers. J. Anim. Physiol. Anim. Nutri. DOI: $10.1111 /$ jpn.12368.

Onyeanusi BI. 2007. Serum Progesterone Concentrations in Indigenous Nigerian Guinea fowls. Int. J.Poult. Sci. 6:608-609.

Oso AO, GA Williams, AV Jegede, RA Sobayo, OMO Idowu, AO Fafiolu, OM Sogunle, OS Akinola, OO Adeleye, IAR Olorunsola, IM Ogunade, SO Osho, FO Obadire and AM Bamgbose. 2014. Effect of combination of whole millet feeding and mannanoligos saccharides supplementation on growth performance, serum biochemistry and relative organ weights of growing guinea fowl (Numidia meleagris). Livest.Sci, 159:46-52.

Park JH and IHKim. 2014. Supplemental effect of probiotic Bacillus subtilis B2A on productivity, organ weight, intestinal Salmonella microflora, and breast meat quality of growing broiler chicks. Poult. Sci. 93:1-6.

Pérez R. 1995. Molasses. In: Tropical Feeds and Feeding Systems, First FAO Electronic Conference.

Raeesi M, A Roofchaee, AZ Shahneh and MBP Zanousi. 2012. Effects of transient hypo- and hyper-thyroidism on growth performance, organ weights and serum levels of thyroid hormones in broiler chickens. Afr. J. Biotechnol. 11:1529-1534.

Rahim AGA, ATE Eiman, NM El-Bagir and SA Haseeba. 1999. Effects of feeding different levels of sugar cane molasses to broiler chicks: feed intake, body weight gain, efficiency of feed utilization and dressing percentage. Sudan J. Vet. Sci. Anim. Husb. 38:93-101.

Riis PM and A Madsen. 1985. Thyroxine concentration and secretion rates in relation to pregnancy, lactation and energy balance in goats. J.Endocrinol.107:421-427.

Rinttila T and J Apajalahti. 2013. Intestinal microbiota and metabolites-Implications for broiler chicken health and performance. J. Appl.Poult Res. 22:647-658.

Roediger WE and S Nance. 1986. Metabolic induction of experimental ulcerative colitis by inhibition of fatty acid oxidation. Br. J. Exp.Pathol. 67:773-782.

Savage DC. 1991. Gastrointestinal microbial ecology: Possible modes of action of direct-fed microbials in animal production. Pp 11-81 in Direct-fed Microbials in Animal Production. National Feed Ingredients Association, Des Moines, IA.

Scanes CG. 2011. Hormones and metabolism in poultry, update on mechanisms of hormone action -focus on metabolism, growth and reproduction, Gianluca Aimaretti (Ed.), ISBN: 978-953-307-341-5, InTech, Available from: http://www.intechopen.com/books/update-onmechanisms-of-hormone-action-focusonmetabolism-growth-and reproduction/hormones-and-metabolism-inpoultry.

Schalm OW, Jain NC andCaroll EJ. 1975. Veterinary Haematology, 3rd edition Lea and Febiger, Philedelphia, U.S.A.

Sinkalu VO, Ayo JO, Ariyo AA and Josiah El. 2014. Effects of melatonin on cloacal temperature and erythrocyte osmotic fragility in layer hens during the hot-dry season, J. Appl. Anim. Res. DOI: 10.1080/09712119.2014.888003.

Tanyi J, R Glávits, G Sályi, P Rudas, E Kósa and J Szabo. 1994. Pancreatitis caused by reovirus in guinea-fowl. Avian Pathol. 23:61-77. 
Buhari Habibu et al./Animal Production. 18(2):102-112, May 2016

Accredited by DGHE No. 81/DIKTI/Kep./2011. ISSN 1411-2027

Todini L. 2007. Thyroid hormones in small ruminants: effects of endogenous, environmental and nutritional factors. Anim. 1: 997-1008.

Zhu W, D Li, J Wang, H Wu, X Xia, W Bi, H Guan and L Zhang. 2015. Effects of polymannuronate on performance, antioxidant capacity, immune status, cecal microflora, and volatile fatty acids in broiler chickens. Poult. Sci.94:345-52. 